\title{
ETNOOBRAZY I STEREOTYPY NARODOWE W POWIEŚCI FANTASY NIKI RAKITINEJ GONITWA I POWIEŚCI SENSACYJNEJ ANDRZEJA KURKOWA DOBRY ANIOE ŚMIERCI
}

\author{
Siergiej Kowalow ${ }^{1}$ \\ (Uniwersytet Marii Curie-Skłodowskiej, Lublin)
}

\begin{abstract}
Słowa kluczowe: rosyjskojęzyczna literatura Białorusi i Ukrainy, tradycja narodowa, gatunek fantasy, powieść sensacyjna, etnoobrazy i stereotypy narodowe, intertekstualność, gra postmodernistyczna

Keywords: Russian-language literature of Belarus and Ukraine, national tradition, fantasy genre, action-packed novel, ethnic images and national stereotypes, intertextuality, postmodern game
\end{abstract}

\begin{abstract}
Abstrakt: Siergiej Kowalow, ETNOOBRAZY I STEREOTYPY NARODOWE W POWIEŚCI FANTASY NIKI RAKITINEJ GONITWA I POWIEŚCI SENSACYJNEJ ANDRZEJA KURKOWA DOBRY ANIOŁ ŚMIERCI. „PORÓWNANIA” 2 (21), 2017, S. 179-196. ISSN 1733-165X. Artykuł dotyczy funkcjonowania etnoobrazów i stereotypów narodowych w rosyjskojęzycznej literaturze Białorusi i Ukrainy na przykładzie powieści fantasy młodej pisarki białoruskiej Niki Rakitinej Gonitwa oraz powieści sensacyjnej znanego pisarza ukraińskiego Andreja Kurkowa Dobry anioł śmierci. Wybrane do analizy utwory należą do różnych literatur narodowych i reprezentują odmienne gatunki literackie, mimo to przekonująco świadczą o artystycznym potencjale związanym z wykorzystaniem przez pisarzy współczesnych tradycji narodowych oraz podejmowaniem gry literackiej z narodowymi kodami i obrazami.
\end{abstract}

\begin{abstract}
Siergiej Kowalow, ETHNIC IMAGES AND NATIONAL STEREOTYPES IN THE FANTASY-NOVEL GONITWA BY NICKY RAKITINA AND THE ACTION-PACKED NOVEL GOOD ANGEL OF DEATH BY ANDREY KURKOV. “PORÓWNANIA" 2 (21), 2017, P. 179-196. ISSN 1733-165X. On the example of the fantasy-novel Gonitva written by a young Belarusian author Nicky Rakitina and action-packed novel Good Angel of Death by Andrey Kurkov, the article presents an analysis of the way ethnic images and stereotypes function in the Russian-language
\end{abstract}

1 E-mail: skowalow@wp.pl 
literature of Belarus and Ukraine. Works chosen for the analysis belong to the different national literatures and different genres, but clearly indicate the prospects of how writers can turn their views on the national traditions and play with national codes and images.

Na Białorusi i na Ukrainie intensywnie rozwija się ostatnio literatura piękna pisana $\mathrm{w}$ języku rosyjskim. Fenomen ten tłumaczy się z jednej strony wielowiekową tradycją wielojęzyczności literatur białoruskiej i ukraińskiej (na przykład w epoce Renesansu używano łaciny, staro-cerkiewno-słowiańskiego, polskiego i starobiałoruskiego), z drugiej zaś działaniem polityki rusyfikacji, intensywnie prowadzonej na terenach białoruskich i ukraińskich w czasach Imperium Rosyjskiego i ZSRR.

Stwarza to oczywiście problemy z określeniem przynależności narodowej rosyjskojęzycznych pisarzy z Białorusi i Ukrainy: ich koledzy, piszący w języku rdzennej nacji, i część literaturoznawców zaliczają pisarzy rosyjskojęzycznych do literatury rosyjskiej, inna część badaczy uznaje natomiast twórczość w języku rosyjskim za ważną składową współczesnej kultury narodowej Białorusi i Ukrainy (co ciekawe, po tym, jak Swietłana Aleksijewicz otrzymała Nagrodę Nobla, liczba przeciwników literatury rosyjskojęzycznej zauważalnie spadła).

Poświęciwszy problemowi wielojęzyczności literatury białoruskiej kilka publikacji (Kowalow 91-114; Kavalou 257-266), uważam, że współczesna literatura Białorusi i Ukrainy jest zjawiskiem heterogenicznym (tak jak łacińsko - i polskojęzyczna literatura Białorusi i Ukrainy w wiekach XVI-XIX) i należy do kilku kultur jednocześnie: rosyjskiej (według kryterium językowego) i białoruskiej albo ukraińskiej (według kraju zamieszkania autora i treści dzieła). Zagrożeniem dla rozwoju współczesnej literatury białoruskiej nie jest literatura rosyjskojęzyczna, ale te społeczno-polityczne i ekonomiczne warunki, w których istnieją obydwie literatury i które sprzyjają wzrostowi twórczości rosyjskojęzycznej na Białorusi: przesunięcie języka białoruskiego ze sfery aktywnego wykorzystania do sfery kulturowej, utożsamienie przez władze niepaństwowych białoruskojęzycznych publikacji z opozycyjnymi, sprowadzanie białoruskojęzycznych czytelników do rangi elitarnego klubu „miłośników literatury narodowej”, wpływ potężnego i pociągającego autorów rosyjskiego rynku wydawniczego itd. (Kavalou 266).

Co więcej, niektóre utwory rosyjskojęzycznych autorów z Białorusi i Ukrainy zawierają wyraźny komponent narodowy, nierozerwalnie związany z lokalną tradycją literacką, prezentują aktualną dla danego kraju problematykę oraz z powodzeniem operują etnoobrazami i stereotypami narodowymi. Szczególnie ciekawe jest to, że problemy i stereotypy narodowe trafiają nie tylko do gatunków wysokich (liryka obywatelska, dramat historyczny, powieść psychologiczna), ale też do niższych, do tzw. literatury popularnej: kryminałów, thrillerów mistycznych i romansów.

Powyższą tezę wyraźnie potwierdzają powieść białoruskiej pisarki Niki Rakitinej Gonitwa (Rakitina) i powieść ukraińskiego beletrysty Andreja Kurkowa Dobry anioł śmierci (Kurkow 2008). Pierwszy utwór należy do gatunku fantasy i przedstawia Białoruś w perspektywie historyczno-mitologicznej, drugi należy do literatury 
sensacyjnej i bazuje na społeczno-politycznych i gospodarczych realiach Ukrainy lat dziewięćdziesiątych XX wieku. Tak różne z punktu widzenia gatunkowego utwory wybrałem do analizy porównawczej celowo, żeby podkreślić niezależny od tematyki i gatunku utworów uniwersalizm stereotypów narodowych i etnoobrazów w literaturze rosyjskojęzycznej Białorusi i Ukrainy, a także aby ukazać ich aktywne funkcjonowanie zarówno poprzez odwołania samych autorów do legendarnej przeszłości, jak i w literackim opisie wciąż aktualnej współczesności.

\section{Debiutantka z Homla i znany pisarz z Kijowa: w kręu rosyjskiej i narodowej przestrzeni kulturowej}

Przy opisie tematu ważne wydaje się zwrócenie uwagi na dyspozycje autorskie i trajektorie kariery Rakitiny i Kurkowa, a także na miejsce tych pisarzy w literaturze Białorusi, Ukrainy i Rosji.

Niki Rakitina (właśc. Ludmiła Bahdanawa) urodziła się w 1963 roku w Homlu (Białoruś). Po ukończeniu szkoły średniej podjęła w 1980 roku studia na Homelskim Uniwersytecie Państwowym imienia Franciszka Skaryny na kierunku rosyjski i białoruski język i literatura. Po studiach pracowała jako nauczycielka w homelskich szkołach, przez pewien czas była doktorantką w Instytucie Literatury Akademii Nauk Białorusi (Mińsk), gdzie zajmowała się twórczością swojego ulubionego pisarza Uładzimira Karatkiewicza. Kariera naukowa nie była jej jednak pisana, Bahdanawa wróciła do rodzinnego Homla, gdzie założyła pierwszy w historii miasta klub rycerski, a obecnie kieruje dziecięcym kółkiem literackim.

Pomimo zachwytu od lat szkolnych nad twórczością Karatkiewicza, Bahdanawa zaczęła pisać w języku rosyjskim: początkowo wiersze, później opowiadania fantastyczne, powieści fantasy. Jej kształtowanie się jako pisarki miało miejsce $\mathrm{w}$ rosyjskiej przestrzeni kulturalnej poprzez udział w konkursach internetowych i warsztatach dla twórców gatunku fantasy ",Bastkon”, , Rostkont”, w kursach Moskiewskiego Klubu Miłośników Fantastyki. Nie dziwi, że opowiadania autorki z Homla można znaleźć $\mathrm{w}$ rosyjskich czasopismach i antologiach poświęconych fantastyce, wydanych w Moskwie, Sankt Petersburgu, Jekaterynburgu. Wprawdzie ukazało się także kilka publikacji wydanych na Białorusi, ale są to $\mathrm{w}$ dużej mierze tłumaczenia z języka rosyjskiego albo publikacje we współautorstwie, dlatego trudno ocenić, w jakim stopniu Rakitina włada jako pisarka językiem białoruskim.

Swoją pierwszą książkę wydała dosyć późno - w 2008 roku, w wieku czterdziestu pięciu lat, ale jej debiutancka Gonitwa (Hanitwa) okazała się sukcesem. Powieść została nagrodzona dyplomem za najlepszy debiut na międzynarodowym seminarium fantasy „Eurokon” w Moskwie (była to pierwsza w trzydziestopięcioletniej historii seminarium nagroda dla autorki z Białorusi). Pomimo udanego debiutu i głośnego oddźwięku w prasie dalsza kariera autorki z Homla nie nabrała rozpę- 
du: w 2011 roku nieduże mińskie wydawnictwo Bukmaster opublikowało wczesną powieść pisarki Wiedźma i wznowiło Gonitwę, późniejsze powieści Rakitiny - Tęcza, Krypta (we współautorstwie z Aleną Olszańską i Nikiem Sredzinem), Popiót (we współautorstwie z Tatianą Kuchtą), Jutrzejszy wiatr (na motywach gier komputerowych Morrowind i Oblivion), Noc spadajacej gwiazdy (we współautorstwie z Natalią Miedziańską) oraz Księga statków (we współautorstwie z Natalią Miedziańską) jak dotąd nie znalazły swojego wydawcy.

Analiza biografii i twórczości Rakitiny pozwala wysnuć następujący wniosek: autorką Gonitwy jest amatorka z Homla, która w odróżnieniu od swoich rodaków i rówieśników - Anatola Sysa, Eduarda Akulina, Alesia Bialackiego - nie zapisała się na stałe w literaturze białoruskiej, a podjęła jedynie próbę realizacji swoich twórczych ambicji w rosyjskiej przestrzeni kulturowej, w której jej ulubiony gatunek fantasy był bardziej rozwinięty. Paradoks polega na tym, że sukces literacki odniosła tylko raz i to dzięki odwołaniu do kontekstu narodowego - wykorzystaniu w powieści Gonitwa białoruskiej mitologii, folkloru, języka, aluzji literackich i historycznych.

Andrej Kurkow urodził się w 1961 roku we wsi Budogoszcz w obwodzie leningradzkim (Rosja). Gdy miał dwa lata, jego rodzina przeniosła się do Kijowa. W stolicy Ukrainy Andrej Kurkov skończył szkołę, Kijowski Państwowy Pedagogiczny Uniwersytet Języków Obcych (1983). Służbę wojskową odbył również na Ukrainie, był strażnikiem w odeskiej kolonii karnej (ciekawy epizod w biografii przyszłego pisarza). Przez pewien czas wykładał w Kijowskim Instytucie Teatralnym, pracował jako scenarzysta w Studiu Filmowym im. O. Dowżenki, następnie zajął się wyłącznie działalnością literacką. Mieszka w Kijowie.

Pisząc od wczesnych lat $w$ języku rosyjskim, Kurkow jako autor stał się znany nie w Rosji, a na Ukrainie oraz w krajach Europy Zachodniej (w Szwajcarii, Niemczech, we Francji). Wejście na zachodni rynek umożliwiła mu znajomość języka angielskiego oraz małżeństwo z Angielką Elizabeth Sharpe - konsultantką w kijowskim oddziale British Council. Swoją pierwszą powieść Nie prowadź mnie do Kengarax (1991) Kurkow wydał na koszt własny, pierwszy sukces komercyjny na Ukrainie przyniosła mu powieść Pokój Bickforda (1994) o konflikcie chorwacko-bośniackim, a wydawców zachodnioeuropejskich zainteresowała jego książka Piknik na lodzie (1997) o bandyckim Kijowie lat 90. XX wieku. Szwajcarskie wydawnictwo Diogenes wykupiło u pisarza prawa do jego utworów (oprócz publikacji na terytorium Ukrainy i Rosji), znane wydawnictwo Folio z Charkowa posiada wyłączność na publikację utworów Kurkowa na Ukrainie, wreszcie w 2005 roku - dosyć późno - twórczością kijowskiego pisarza zainteresowało się rosyjskie wydawnictwo Amfora (Sankt Petersburg). Co ciekawe, niektóre teksty Kurkowa zostały przetłumaczone na język ukraiński, a sam autor należy do Krajowego Związku Pisarzy Ukrainy od 1994 roku.

Możliwe, że nieufny i chłodny stosunek rosyjskiego rynku wydawniczego do twórczości Kurkowa sprzyjały wzrostowi jego narodowego patriotyzmu, samoidentyfikacji jako rosyjskojęzycznego Ukraińca. Przeszkodą na drodze do komer- 
cyjnego sukcesu Kurkowa w Rosji mogła być wybrana przez niego problematyka ukraińska, geopoetyka jego utworów: akcja większości z nich toczy się na Ukrainie (Piknik na lodzie, Dobry anioł śmierci, Ostatnia miłość prezydenta, Prawo ślimaka, Lwowski występ Jimiego Hendrixa, Dziennik z Majdanu). Rosyjskie wydawnictwa często zmuszają mało znanych autorów z Białorusi i Ukrainy, aby przenosili oni akcję swoich utworów z Mińska albo Kijowa do Moskwy czy Sankt Petersburga, co jest nie do przyjęcia dla pisarza pokroju Kurkowa. Z drugiej strony, zauważalny wzrost zainteresowania wydarzeniami na Ukrainie $\mathrm{w}$ krajach europejskich znacząco sprzyja sukcesowi komercyjnemu jego powieści na Zachodzie, wyraziste cechy ukraińskie jego utworów oraz demokratyczna, antyputinowska pozycja autora stanowią tutaj nie przeszkodę, a dodatkowy atut dla wydawców i czytelników:

Jeżeli artysta jest obywatelem Ukrainy i pracuje w Ukrainie, to tworzy równocześnie ukraiński produkt kulturowy. [...] Ja uważam się za pisarza ukraińskiego, jednak wielu moich kolegów mysli inaczej. [...] Wielu z nich podziela iluzję, że za ukraińskie można uznać tylko to, co jest czysto etnicznie ukraińskie. [...] Przedstawiciele kulturowego etnocentryzmu często nie rozumieją, że kultura ukraińska składa się tak naprawdę z twórczości wszystkich mniejszościinarodów, którezamieszkują terytorium kraju (Kurkow 2012,150).

Ogląd biografii oraz twórczości Kurkowa, a także lektura poświęconych mu materiałów prasowych uzasadnia tezę, że urodzony z Rosji pisarz wyraźnie zajmuje pozycję jako autor ukraiński, mieszkaniec Kijowa, obywatel Ukrainy.

\section{Okupowany kraj}

Akcja Gonitwy Rakitinej toczy się w latach 1828-1831 w malutkim kraju Leitavie, zaanektowanym na początku XIX wieku przez księstwo schoenewaldzkie. Niepokorni mieszkańcy Leitavy przygotowują kolejne powstanie, wykorzystując do walki z okupantem wszelkie środki, w tym również magiczne. Pomiędzy miastami i wsiami kursują tajemniczy Gońcy, po bagnach kłusuje siejąca strach Gonitwa (Dzikie Polowanie), a zbuntowany książę Aleś Wiedrycz przy pomocy zaklęć przywraca do życia pogrzebaną już hrabinę Sewerynę Marżecką, oskarżoną o zdradę, i zamienia ją najpierw w rusałkę, a następnie w boginię zimy Morenę, uśmiercającą spotykanych na swojej drodze okupantów i przy okazji wszystko, co żywe. Plany Wiedrycza usiłują pokrzyżować, z jednej strony, potomek starożytnych władców kraju Gevoitas, który uważa używanie czarnej magii za niedozwolone i niebezpieczne; z drugiej - generał schoenewaldzki, były generał-gubernator Leitavy Heinrich Eisenwald, zakochany w Sewerynie i przekonany, że hrabina tak naprawdę nikogo nie zdradziła.

Kraj Leitava w świadomości czytelników Gonitwy niedwuznacznie kojarzy się z historyczną Litwą i dzisiejszą Białorusią (autor nie zmienił nazwy stolicy: Wilno), 
natomiast księstwo Schoenewald - zarówno z Prusami, jak i z Rosją (część okupantów nosi nazwiska niemieckie, część rosyjskie). Rakitina poświęciła swoją powieść „bohaterom polskiego powstania 1931 r." (Rakitina 3), które - jak wiadomo - było powstaniem polsko-litewsko-białoruskiej szlachty przeciwko rosyjskiemu panowaniu. Białoruscy krytycy przyjęli Gonitwę jako pierwszą białoruską powieść o powstaniu lat 1930-1931 (Zaprudski 200). Ponieważ jednak Gonitwa nie jest powieścią historyczną, ale fantasy z elementami alternatywnej historii, decyzją autorki Leitava znajduje się pod okupacją nie rosyjską, ale niemiecką. W odróżnieniu od historycznego powstania w 1931 roku bunt leitavskich patriotów w Gonitwie kończy się długo wyczekiwanym zwycięstwem i uwolnieniem Wilna spod władzy okupantów.

Warto zauważyć, że motyw okupacji był zawsze popularny w białoruskiej literaturze i sztuce. W czasach radzieckich konkretyzował się jako obraz niemiecko-faszystowskiej okupacji lat 1941-1944, w okresie pierestrojki i odrodzenia narodowego - jako obraz okupacji rosyjskiej imperialnej i radzieckiej komunistycznej, a obecnie pełni funkcję uniwersalnego archetypu, określającego specyfikę świadomości i charakteru Białorusina ${ }^{3}$. Symptomatyczne, że jeden z najlepszych białoruskich filmów fabularnych ostatniej dekady nosi tytuł Okupacja. Misteria (2004), a kolejny film tego reżysera, Andreja Kudinienki, to Masakra (2010), nakręcona według motywów noweli Prospera Mérimée Lokis i określana przez krytyków jako otwarcie antykolonialna (Rasinski 101).

Obraz Leitavy jako okupowanej przez najeźdźców Ojczyzny zajmuje istotne miejsce w powieści Rakitinej i wpisuje się w najlepsze tradycje białoruskiej prozy historycznej na czele z Karatkiewiczem, którego twórczość wywarła znaczący wpływ na młodą pisarkę. W powieści nie obeszło się bez ponurych, mrocznych pejzaży w stylu Dzikiego polowania króla Stacha:

Zakamary bagien z powykręcanymi, suchymi sosnami i łysiejącą osiką, z poczerniałymi szyszkami na olchach, a między nimi suche „kurhany olbrzymów”: kraina kuriozalna, nieprawdziwa, nie nadająca się do życia. Pełzające jęzory paproci. Szelesty, szmery i chmary komarów ${ }^{4}$ (Rakitina 35).

2 „героям польского восстания 1831 года”. Tu i dalej przekład cytatów na język polski Małgorzaty Buchalik.

3 Patrz np. powieści Artura Klinowa Pikielhauba (2011) i Skup butelek (2013). W drugiej z nich czytamy: „Думаю, справа уे народзе. Ён за стагоддзі так прызвычаіўся жыць пад акупацыяй, што кожная уллада яму чужая. [...] Усялякая уллада для яго - непазбежнае зло, з якім ён мусіць проста змірыщца. Такі чалавек кажа сабе: “Мая хата з краю, нічога я не ведаю і ведаць не хачу!” Перад ім стаіць адна задача - выжыць на акупаванай тэрыторыі. [Myślę, że chodzi o naród. Przez setki lat tak przywykł żyć pod okupacją, że każda władza jest dla niego obca. [...] Każda władza jest dla niego nieuniknionym złem, z jakim musi się zwyczajnie pogodzić. Taki człowiek mówi sobie: „To nie mój cyrk, ja tam nic nie wiem i ani myślę wiedzieć!" Stoi przed nim jedno tylko zadanie - przetrwać, zachować życie na okupowanym terytorium]" (Klinau 121).

4 „Языки болот со скрюченными сухими елками и лысеющими осинами, с почерневшими шишечками на ольхах, а между ними сухие холмы-волотовки: вычурный, неверный, не способный к жизни край. Ползучие языки папоротника. Шелест, шорох, комариный зуд". 
Często spotkamy tu bezpośrednie, krótkie, ale bardzo emocjonalne i metaforyczne opisy: „Leitava to dziwny kraj. Jednocześnie dziki i łagodny”5 (Rakitina 184); „....do Leitavy, dzikiej, przeklętej przez boga krainy, brzemiennej powstaniami jak źrebna kobyła" (Rakitina 210).

Specyficzna mentalność mieszkańców Leitavy również wywołuje u czytelnika nieuchronne skojarzenia ze specyfiką charakteru narodowego Białorusinów. Oczywiście Leitavianie lubili dobrze zjeść:

Od samych tylko zapachów można było oszaleć: słonina wędzona i kiszona z tymiankiem i grubą czarną solą, kiełbasa wieprzowa, salceson, kaszanka, kiszone ogórki, kiszona kapusta i marynowany chrzan; kołacz okrągły jak słońce, pierogi z wiśniami na zimno; lody śmietankowe, masło i ser z dziurami, twaróg... w Leitavie znano się na kuchni i umiano jeść ${ }^{7}$ (Rakitina 184-185).

Przyjęło się chwalić Białorusinów za dobroduszność, tolerancję wobec ludzi innych narodowości i innego wyznania, ale też jednocześnie wytykać im brak dumy narodowej i chęci walki o swoją wolność i niepodległość. Podobne zarzuty pojawiają się również w Gonitwie: „Bardzo szanuję wasz lud, jego tolerancję religijną, jego pracowitość, zachwycające hafty i pieśni. Ale pewnych rzeczy ... po prostu nie rozumiem! Poniżają was, a wy pokornie zginacie karku jak niewolnicy!"8 (Rakitina 27) - dziwi się Niemka z pochodzenia i leitavska patriotka z przekonania, baronessa Frania Zweinziger, postać wzorowana na prawdziwej postaci historycznej, bohaterce powstania lat 1830-1831 Emilii Plater.

Zbytnią tolerancję i pokorę ludu Leitavy kompensuje sprzeciw samej ziemi, która nie pogodziła się z obecnością okupantów i rodzi w swym łonie potwory, infernalne moce w rodzaju Gonitwy:

...Straż. Ni to jeździec, ni to krzyż, ni to omszały pień. Wytwór bagiennych oparów, mgły, nienawiści do okupantów. [...] Wytwór udręczonej ziemi, która nie zdołała zrzucić obcych rękami swoich dzieci. Dzieci okazały się słabe i niegotowe. A ona nie chciała poddać się najeźdźcom. Zhańbiona kobieta umiera, godzi się z losem albo chwyta za miecz. A właściwie za kosę. I kosi tą kosą winnych i niewinnych. Swoich i obcych. Straż. Gonitwa. Mrok (Rakitina 345).

5 „Лейтава - странная страна. Дикая и нежная одновременно”.

6 „...в Лейтаву, дикую, проклятую богом страну, чреватую восстаниями, как жеребая кобыла”.

7 „От одних запахов можно было рехнуться: копченое и соленое с тмином и крупной солью сало, свиная колбаса, зельц, кровянка, соленые огурцы с капустой и маринованный хрен; круглый, как солнце, каравай, холодные вареники с вишней; круг мороженого молока, масло и сыр со слезой, творог... поесть на Лейтаве знали и умели".

8 „Я Я очень уважаю ваш народ, его терпимость в вопросах веры, его трудолюбие, удивительные вышивки и песни. Но некоторого... я просто не понимаю! Вас унижают, а вы гнетесь в рабской покорности!".

9 „...Стража. Не то вершник, не то крест, не то замшелый пень. Порождение болотных испа- 
Ale też niewolnicza pokora mieszkańców Leitavy jest tylko pozorna. Wystarczyło, że na oczach chłopów oddział karny zbezcześcił ciało jednego z Gońców, a spokojni, posępni chłopi łapią za widły i wyrzynają doborowych żołnierzy niemieckich bez jednego wystrzału w odpowiedzi.

Stworzony przez Rakitinę tajemniczo-uwodzicielski obraz Leitavy nawiązuje, po pierwsze, do realnej historycznej Białorusi XIX wieku; po drugie, do bogatej polsko-białoruskiej tradycji literackiej: od Adama Mickiewicza po Uładzimira Karatkiewicza; po trzecie zaś do tradycji przedstawiania obrazu starożytnego, pokonanego przez najeźdźców, ale niepogodzonego z tym kraju w zachodnioeuropejskiej i słowiańskiej literaturze fantasy (Clive Staples Lewis, Guy Gavriel Kay, Marija Siemionowa i inni). Obraz Leitavy autorka buduje, nawiązując do licznych legend i wierzeń (pochodzenia zarówno słowiańskiego, jak i bałtyckiego), stosując frazeologizmy i elementy folklorystyczne oraz wplatając białoruską leksykę w podstawową, rosyjskojęzyczną osnowę powieści.

Język rosyjski Gonitwy, poprzez który przebijają się na powierzchnię odłamki „zapomnianego" języka ojczystego, wygląda na świadomy chwyt literacki, podkreślający nostalgię, ujmujący ból wywołany przez odchodzący w przeszłość romantyczny obraz Białorusi-Litwy.

\section{Moskal, Chochoł i SBU}

Książka Kurkowa Dobry aniot śmierci należy do odmiennego gatunku i traktuje o innych czasach, dlatego też rysuje przed nami całkiem inny obraz ojczyzny niż Gonitwa Rakitinej.

Akcja powieści Kurkowa toczy się w latach dziewięćdziesiątych ubiegłego wieku, wkrótce po rozpadzie ZSRR: na Ukrainie i w Kazachstanie, a także w drodze z Ukrainy do Kazachstanu i z powrotem. W ręce mieszkańca Kijowa, Nikołaja Sotnikowa, wpadają tajemnicze notatki, spuścizna dysydenta-szestidiesiatnika Wiaczesława Herszowicza, które doprowadzają go na półwysep Mangystau, gdzie niegdyś służył w carskiej armii Taras Szewczenko, przyszły klasyk literatury ukraińskiej. Bohater ma nadzieję odzyskać rękopis wielkiego pisarza. Okazuje się jednak, że tajemnicza relikwia zainteresowała nie tylko Rosjanina Sotnikowa, ale też ukraińskiego nacjonalistę, członka UNA-UNSO Petra Rohula, oraz pułkownika Służby Bezpieczeństwa Ukrainy Witolda Taranenkę. Wszyscy oni spotykają się na Mangystau i odkrywają, że cenny artefakt to nie manuskrypt Szewczenki, ale prze-

рений, тумана, ненависти к завоевателям. [...] Порождение истерзанной земли, которая не смогла сбросить чужаков руками своих детей. Дети оказались слабы и не готовы. А она не хотела покориться завоевателям. Поруганная женщина умирает, смиряется или берет меч. Вернее, косу. И сметает этой косой правых и виноватых. Своих и чужих. Правых и виноватых. Стража. Гонитва. Тьма". 
sycony duchem narodowym piasek wokół fortu, gdzie służyli pisarz i inni ukraińscy rekruci. Cudowny piasek zbawiennie oddziałuje na ludzi w pobliżu: dzięki niemu stają się mniej źli i agresywni, są lepsi i mądrzejsi, budzą się w nich najlepsze cechy charakteru właściwe narodowi ukraińskiemu. Wspólnym wysiłkiem bohaterowie dostarczają wagon cennego piasku na Ukrainę, gdzie ma on zostać wykorzystany do odrodzenia ducha narodowego w kraju i, przede wszystkim, na Krymie (sądząc po wydarzeniach ostatnich lat, eksperyment niezbyt się udał - S.K.).

Trzech bohaterów powieści, którzy spotykają się z woli autora na odległej kazachstańskiej pustyni, to przekrój społeczeństwa ukraińskiego lat dziewięćdziesiątych XX wieku, i zresztą również dzisiejszego. Każdy z nich ma na wyspie własne cele, własne wyobrażenie o ojczyźnie, i każdy przechodzi zupełnie inną metamorfozę pod wpływem cudownego piasku i niezwykłych wydarzeń.

Rosjanina z pochodzenia, ale szczerze kochającego swój rodzinny Kijów, Nikołaja Sotnikowa zaprowadziły na półwysep Mangystau okoliczności życiowe, pusta ciekawość i przyziemne pragnienie sławy i pieniędzy, które zapewni mu odnalezienie tak ważnej dla Ukraińców relikwii:

Ciekawe - pomyślałem - ile by zapłacili za nieznany rękopis Szewczenki na aukcji gdzieś, na przykład, w Kanadzie? Mieszkają tam najbogatsi i najbardziej sentymentalni Ukraińcy i właśnie któryś z nich mógłby ze łzami w oczach, rozczulony, wydać kilka milionów dolarów, niech już nawet kanadyjskich ${ }^{10}$ (Kurkow 2008: 29-30).

W miarę zbliżania się do celu motywacja bohatera staje się jednak szlachetniejsza i mniej wyrachowana: „Byłoby świetnie - pomyślałem - gdyby to mnie, Rosjaninowi, udało się odnaleźć te szkice Kobziarza. Niezły wkład w rozwój przyjaźni miedzy dwoma bratnimi narodami, co? ${ }^{11 "}$ (Kurkow 2008: 68). Kiedy rosyjskojęzyczny mieszkaniec Kijowa Nikołaj Sotnikow dociera w końcu na miejsce i czuje na własnej skórze magiczne działanie cudownego piasku, zaczyna myśleć po ukraińsku, śnićsny o historii Ukrainy i zachwycać się połączeniem żółci i błękitu w pejzażu wyspy; rozumie wówczas, że najcenniejsze, co znalazł na dalekiej obczyźnie, to miłość do Kazaszki Guli, która później zostaje jego żoną. Tak więc bohater w wyniku przemian staje się bogatszy duchowo i, co ważne, pośród owych bogactw duchowych zyskuje na równi z miłością także znajomość języka ukraińskiego i poczucie wspólnoty z przeszłością i przyszłością Ukrainy.

10 „Интересно, - подумал я, - а сколько бы предложили за неизвестную рукопись Шевченко на аукционе где-нибудь в Канаде? Там живут самые богатые и самые сентиментальные украинцы, а именно один из таких и мог бы со слезами умиления на глазах выложить парочку миллионов пусть хоть канадских, но долларов".

11 „Было бы славно, - подумал я, - если б мне, русскому человеку, удалось найти эти записи Кобзаря. Чем не вклад в развитие дружбы между двумя братскими народами?". 
Pułkownik SBU Witold Taranenko początkowo przedstawiony zostaje jako bezduszny, pragmatyczny funkcjonariusz, zawzięty służbista, rugający ukraińskiego patriotę i idealistę Petra Rahulę za udział w wydarzeniach politycznych:

Wąsaty adidasowiec przystanął nad Petrem, świdrując go wrednym spojrzeniem:

- No co? - spytał nieoczekiwanie łagodnie, lekko nachylając się i zawisając twarzą nad głową Petra. - Mało ci było urządzać po całym Kijowie demonstracje i inne paskudztwa, jeszcze i do Kazachstanu dotarłeś?! Poczekaj, ja ci pokażę, jak tylko wrócimy do domu! Mamy o tobie cały film wideo! ${ }^{12}$ (Kurkow 2008: 148).

W odróżnieniu od rosyjskojęzycznego Sotnikowa („Moskala”, jak go nazywa Rahula) i mówiącego po ukraińsku Rahula („Chochła”, jak go nazywa Sotnikow) pułkownik Taranenko mówi po rosyjsku, wtrącając ukraińskie słowa (niemal w surżyku), i ubiera się w typowy dres Adidasa, przez co wygląda jak bandyta z mafii; jego poglądy polityczne można określić jako postkomunistyczne. Pułkownik narzeka, że niezależna Ukraina obcina finansowanie SBU, i do swojej skromnej (w jego mniemaniu) pensji dorabia poprzez nielegalny handel bronią i półlegalny handel wietnamskim balsamem.

W miarę zacieśniania znajomości z pozostałymi bohaterami i pod wpływem przesyconego duchem narodowym piasku Witold Taranenko ukazuje się nam jako oddany interesom swojego kraju oficer i człowiek niepozbawiony uroku osobistego. Należy do tych funkcjonariuszy bezpieki, którzy starali się w miarę możliwości służyć interesom Ukrainy już w czasach ZSRR i będą z całego serca służyli młodemu niezależnemu państwu (wprawdzie - jako prawdziwi Ukraińcy - nie zapominając o własnych finansach). Pułkownik opowiada Sotnikowowi i Rahulowi o tajnych badaniach nad materialnymi przejawami ducha narodowego, prowadzonych w latach sześćdziesiątych XX wieku, a później znienacka zakazanych przez Moskwę.

Wtedy bezpieka w każdej republice utworzyła taki wydział. Moskwa dawała na te badania dużą kasę. Najwięcej dostaliśmy my, kraje bałtyckie i Tadżykistan. Najmniej Białorusini - bo co tam niby badać... ${ }^{13}[\ldots]$ Już wtedy namierzyliśmy na Ukrainie kilka tak zwanych świętych miejsc. [...] Odkryliśmy też pewną prawidłowość: we wsiach położonych w pobliżu takich miejsc przestępczość była kilkakrotnie niższa od średniej ukraińskiej. Natomiast średnia rozwoju intelektualnego - wyższa ${ }^{14}$ (Kurkow 2008: 200-201).

12 „Усатый "адидасовец" остановился над Петром, сверля его ехидным взглядом.

- Ну шо? - неожиданно бархатно спросил он, слегка наклонившись и зависнув лицом над головой Петра. Мало тебе было по Киеву разные митинги и безобразия устраивать, так ты еще и до Казахстана добрался! Погоди, домой вернемся, я тебе покажу! У нас про тебя целый видеофильм есть!".

13 Kursywa moja - S.K. Słowa bohatera powieści Kurkowa odzwierciedlają popularne przekonanie o poziomie świadomości narodowej Białorusinów - niestety, za czasów ZSRR bliskie prawdzie.

14 „В каждой республике тогда в ГБ открыли по такому отделу. Москва выделила много денег 
Pułkownik Taranenko martwi się o los swojej ojczyzny i działa w interesie młodego, niezależnego państwa, organizując dostawy magicznego piasku na Ukrainę, żeby potem dosypywać go do piaskownic w przedszkolach i wychowywać nowe pokolenie Ukraińców. Paradoksalnie to właśnie funkcjonariusz bezpieki Taranenko pod wpływem promieniowania cudowanego piasku prezentuje najrozsądniejsze i najmądrzejsze poglądy w kwestii narodowej, prawdopodobnie zbliżone do poglądów samego autora powieści:

Petro spojrzał pułkownikowi prosto w oczy. - No to dlaczego ludzie nie przechodzą na ukraiński? Przecież duch narodowy to na początek język narodowy!

- Nie - odpowiedział pułkownik. - Duch narodowy jest ponad językiem narodowym. Zmienia stosunek człowieka do tego, co go otacza, do wszystkiego wokół i do samego siebie. Duch oddziałuje na człowieka każdej narodowości, budząc w nim tylko to, co dobre. A język jest jedynie zewnętrzną cechą narodowości. Równie dobrze może mówić nim prezydent i maniakalny morderca. Jeżeli język traktować jako najważniejszą cechę ducha narodowego, stanie się on narzędziem segregacji, współczesnej inkwizycji. Bo wówczas przemocowiec, mówiący po ukraińsku, stanie się lepszy i porządniejszy niż przemocowiec, mówiący po rosyjsku' ${ }^{15}$ (Kurkow 2008: 206).

Najbardziej drastyczną przemianę przechodzi pod wpływem piasku ukraiński patriota Petro Rahula. Kiedy bohater po raz pierwszy pojawia się na stronicach powieści, idealnie odpowiada stereotypowi „prawdziwego Ukraińca”, który zawsze i wszędzie rozmawia po ukraińsku (nawet z Kazachami i Azerami) i jest wrogo nastawiony do „Moskali” (przy czym urodzonego w Kijowie Sotnikowa również nazywa Moskalem, a Ukraińca Taranenkę krytykuje za mówienie w „obcym języku”; nawet do Tarasa Szewczenki ma pretensje o to, że ten pisał do Agrafii Iwanownej „liściki po rosyjsku”). W jednym z wywiadów Kurkow wyznał, że postać Petra „przeszkicował” z ulotek i proklamacji organizacji nacjonalistycznej UNA-UNSO (Kurkow 2009). Nic dziwnego, że skutek jest ironiczny, czasem wręcz komiczny:

на эти исследования. Больше всего досталось нам, прибалтам и таджикам. Меньше всего белорусам - там, вроде, нечего было исследовать... [...] Уже тогда мы вышли на несколько так называемых священных мест на Украине. [...] Мы определили закономерность: в селах, находящихся вблизи таких мест, преступность была в несколько раз меньше, чем в среднем по Украине. Средний уровень умственного развития был выше".

15 „Петр посмотрел прямо в глаза полковнику. - Але ж чому тоди люды не перэходять тут на украинську мову? Национальный дух - цэ ж спочатку национальна мова!

- Нет, - ответил полковник. - Национальный дух выше национального языка. Он изменяет отношение человека к окружающему, ко всему вокруг и к себе самому. Дух воздействует на человека любой национальности, пробуждая в нем только хорошее. А язык - это лишь внешний признак национальности. На нем одинаково хорошо может говорить и президент, и маньяк-убийца. Если язык перевести в самое важное качество национального духа, он станет инструментом сегрегации, современной инквизиции. Получится, что насильник, говорящий по-украински, окажется лучше и добрее насильника, говорящего по-русски". 
Petro przeniósł spojrzenie z Guli na mnie - Jesteś Rosjaninem, chcesz czy nie, i nigdy nie będziesz Ukraińcem... - i Petro ciężko westchnął, jakby zrobiło mu się nieznośnie żal, że nigdy nie będę Ukraińcem.

- A po co miałbym być Ukraińcem, skoro urodziłem się Rosjaninem?

- Mieszkasz na Ukrainie? - odpowiedział pytaniem na pytanie Petro.

- No to co? Paszport też mam ukraiński.

- Paszport to jedno, a dusza - całkiem co innego. Duszę masz rosyjską, "szy-ro-ką" ... powiedział Petro i zachichotał16 (Kurkow 2008: 253).

I mimo wszystko obraz Petra Rahuli - przy wszystkich jego komicznych cechach - jest niewątpliwie obrazem bohatera pozytywnego, wzbudzającego u czytelników i u narratora, Nikołaja Sotnikowa, sympatię.

Pod murami fortu, w którym służył niegdyś Taras Szewczenko, pod działaniem magicznego piasku Petro staje się mniej agresywny i bardziej przyjacielski, zaczyna mówić po rosyjsku z rosyjskojęzycznymi, a treść jego wypowiedzi wprawia słuchaczy w zdumienie:

Nie jesteśmy nacjonalistami, nie trzeba się nas bać. Nie krzyczeliśmy: Ukraina dla Ukraińców. Jeżeli kochasz Kijów, powinieneś też pokochać Ukrainę. I wcale nie trzeba w tym celu wkładać wyszywanej koszuli ani wieszać nad drzwiami tradycyjnego ręcznika... I wszyscy razem - Ukraińcy, Żydzi, Rosjanie, Kazachowie - zbudujemy europejskie państwo...

Słuchałem Petra w osłupieniu. Nie mieściło mi się w głowie, że mówi to członek UNA-UNSO. Coś tu było nie tak. Nie dość, że zaczął mówić do mnie po rosyjsku, to jeszcze wypowiada myśli prędzej wzięte z Deklaracji Praw Człowieka ONZ niż z programu organizacji, o której celach i zadaniach czytałem w gazetach coś całkiem, ale to całkiem innego"17 (Kurkow 2008: 210).

16 „Петр перевел взгляд с Гали на меня. - Ты - росиянын, як бы ты того нэ хотив, а украйинцэм николы нэ станэш... - и Петр тяжело вздохнул, словно стало ему нестерпимо жаль, что я никогда не стану украинцем.

- А зачем мне становиться украинцем, если я русским родился?

- Ты ж в Украйни жывэш? - вопросом на вопрос ответил Петр.

- Ну и что? И паспорт у меня украинский.

- Паспорт - цэ однэ, а душа - иншэ. Душа в тэбэ росийска, „ши-ро-кая” ... - сказал Петр и хохотнул.

17 Мы не нацисты, и не нужно нас бояться. Мы не заявляли, что «Украина только для украинцев». Если ты любишь Киев, ты должен полюбить и Украину. И совершенно не обязательно для этого надевать сорочку-вышиванку и вешать над дверью рушник... Мы все вместе: украинцы, евреи, русские, казахи - построим европейское государство...

Я остолбенело слушал Петра. В голове не укладывалось, что это речь члена УНА-УНСО. Чтото тут было не так. Мало того, что он заговорил со мной по-русски, он еще и высказывает мысли, созвучные скорее декларации прав человека $\mathrm{OOH}$, чем упомянутой организации, о целях и задачах которой я читал в газетах нечто совершенно противоположное". 
"Chochoł" Rahula udziela schronienia „Moskalowi" Sotnikowowi w domu swoich rodziców w Kołomyi i zostaje jego jedynym bliskim przyjacielem. Wczorajszy buntownik i opozycjonista Rahul po powrocie z wyspy bierze udział w wyborach do Rady Najwyższej i zapewne zostanie posłem, a jego przemiana odzwierciedli zasadniczy zwrot $\mathrm{w}$ rozwoju politycznym Ukrainy na przełomie XX i XXI wieku.

\section{Wiwisekcja patriotyzmu}

Analizując obecność komponentów narodowych w rosyjskojęzycznych powieściach Gonitwa Rakitinej i Dobry anioł śmierci Kurkowa, musimy zatrzymać się na zagadnieniu patriotyzmu, żywo poruszanej przez oboje autorów.

„Staromodna” kwestia patriotyzmu, dręcząca przez kilka wieków klasyczną literaturę białoruską, to jeden z centralnych tematów napisanej w XXI wieku powieści fantasy Rakitinej. Zwracając się ku tradycji białoruskiej prozy historycznej, która stworzyła całą galerię powstańców-patriotów, bojowników o wolność ojczyzny (Tadeusz Kościuszko, Konstanty Kalinowski, Aleś Zahorski i in.), pisarka gruntownie rewiduje pojęcie patriotyzmu, jego źródła i granice moralne.

Jeden z głównych bohaterów powieści, książę Aleś Wiedrycz, fanatycznie kocha ojczyznę i stawia to uczucie ponad przyjaźnią, honorem, miłością do kobiety i wiarą w Boga. „Nie będę kłamał, że cię kocham. Moją jedyną kobietą jest teraz i na wieki Leitava. Ale potrzebuję cię, moja panno Moreno, towarzyszko i bojowniczko ${ }^{18 "}$ (Rakitina 285) - mówi Aleś Wiedrycz do Haili (czyli Seweryny Morżeckiej), starając się zmienić ją w bezlitosnego potwora, w potężną broń w walce z okupantem.

Wiedrycz obwinia o brak patriotyzmu potomka Wężowego Króla Gevoitasa:

Czyście ogłuchli? Czy nie słyszycie, jak ziemia stęka pod butem okupanta? Jak opłakuje swoje martwe dzieci, najlepsze ze swoich dzieci?! Te, które poszły jej bronić, nie szczędząc własnego życia. [...] Do czego wy się teraz nadajecie? Nawet dupy nie chce wam się ruszyć dla ojczyzny... ${ }^{19}$ (Rakitina 327-328).

Za przesadny fanatyzm i ignorowanie norm moralnych dla osiągnięcia celu książę Wiedrycz zostaje wyrzucony z organizacji rewolucyjnej „Straż”; dla uwolnienia ojczyzny gotów jest duszę diabłu zaprzedać i ostatecznie zmienia się w jednego z upiorów, w widmowego jeźdźca Gonitwy. „Ch...wy patriota!20” (Rakitina 219) -

18 „Я не буду лгать тебе, что тебя люблю. Единственная моя женщина сейчас и навеки - Лейтава. Но ты нужна мне, панна моя Морена, соратник и боец".

19 „Но разве вы оглохли? Разве вы не слышите, как земля стонет под пятой завоев«ателя? Как рыдает по своим мертвым детям, лучшим из своих детей?! Тем, что не пожалели жизни, вступившись за нее. [...] А теперь на что вы годные? Лень для родины жопой пошевелить...".

20 „Патриот х...!”. 
wybucha Heinrich Eisenwald, osądzając Wiedrycza w imieniu nie tylko swoim, ale też czytelników.

Nie mniejszym patriotyzmem i zamiłowaniem do patriotycznych wystąpień cechuje się była narzeczona księcia, Antonina Lehnicz, gotowa „....przemienić się w wilka, żeby przegryźć wrogowi gardło" 21 (Rakitina 176). Strata bliskich i nieszczęśliwa miłość rozpaliły nienawiść Antoniny Lehnicz do okupanta, ale nienawiść ta w jej przypadku zaczyna przeradzać się w negację życia jako takiego, a źródła egzaltowanego patriotyzmu kryją się być może w niezaspokojeniu seksualnym. „A to jest właśnie źle pojmowany patriotyzm 22" (Rakitina 167) - myśli o histerycznej panience Lehnicz Heinrich Eisenwald i czytelnicy Gonitwy po raz kolejny muszą przyznać mu rację.

Zwracając się, jak już zaznaczyłem, ku tradycjom białoruskiej prozy historycznej i polskiej literatury romantycznej XIX wieku, postaci Alesia Wiedrycza i Antoniny Lehnicz w powieści Rakitinej Gonitwa są groteskowym odbiciem bohaterskich archetypów i zaprzeczeniem romantycznej zasady "ojczyzna ponad wszystko". Fanatyczny patriotyzm Wiedrycza i Lehnicz, ich dążenie do zniszczenia wroga za wszelką cenę przypominają patriotyzm Czarnego Karła Nikabrika z poczytnych Opowieści z Narni Lewisa: żeby wyzwolić Narnię spod władzy ludzi, Nikabrik gotów jest przy pomocy czarnej magii przywołać do życia okrutną Białą Czarownicę, rządzącą Narnią wiele wieków wcześniej (Lewis 282-292).

Co ciekawe, Rakitina powierzyła osąd moralny swoich bohaterów Niemcowi, Heinrichowi Eisenwaldowi, przedstawicielowi okupantów - ale tylko dlatego, że postać generała przechodzi w powieści ogromną zmianę. Badając na polecenie władz Schoenewaldu tajemnicze wydarzenia w Leitavie, były wileński generałgubernator zdołał zrozumieć i pokochać nie tylko Sewerynę-Haili, ale też jej zadziwiający kraj, i pisze dla władz pacyfistyczny raport, po czym w finale powieści zmienia się w jednego z leitavskich Gońców, następcę Wężowego Króla. Tak więc w przypadku Eisenwalda miłość do kobiety nie koliduje z miłością do ojczyzny, jak u Alesia Wiedrycza, ale utożsamia się z nią, staje się drogą do wolności i odrodzenia duchowego.

W poświęconej współczesności powieści Kurkowa obecne są te same myśli o patriotyzmie, co w opisującej legendarną historię powieści Rakitinej. Na marginesach Kobziarza Tarasa Szewczenki, ukrytego pod okładką Wojny i pokoju Lwa Tołstoja, Nikołaj Sotnikow znajduje notatki dysydenta-szestidiesiatnika Wiaczesława Herszowicza o patriotyzmie, bliskie jego własnym refleksjom: „Patriotyzm głodnego to próba odebrania kromki chleba obcemu, patriotyzm sytego to budząca szacunek wielkoduszność23" (Kurkow 2008: 5).

21 „...превратиться в волка, чтобы вцепиться в горло врага".

22 „Вот он, ложно понятый патриотизм”.

23 „Патриотизм голодного - это попытка забрать ломоть хлеба у инородца, патриотизм сытого - великодушие, вызывающее уважение". 
Pod wpływem propagandy komunistycznej, następnie zaś wydarzeń politycznych lat dziewięćdziesiątych XX wieku i odrodzenia idei narodowych i szowinistycznych, pojęcia patriotyzmu i postać patrioty na terenach proradzieckich istotnie się zmieniły. Warto zwrócić uwagę na dwa momenty w powieści Kurkowa: rozmowę Nikołaja Sotnikowa z astrachańską sprzedawczynią Niurką i jego próbę wyjaśnienia, kim był Taras Szewczenko, pracowniczce astrachańskiej pływającej przetwórni rybnej, Daszy.

Tłumacząc Niurce, w jakim celu jedzie na Mangystau, Sotnikow mówi, że chciałby dotknąć piasku, po którym stąpał Taras Szewczenko. Niurka reaguje na to tak: "Co za czasy! - westchnęła. - Kiedyś chodzili szlakiem a to Lenina, a to Breżniewa, a teraz każda republika ma własnego idola24" (Kurkow 2008: 58, podkr. S.K.).

Prosta rosyjska dziewczyna Dasza, słysząc od Sotnikowa nazwisko Tarasa Szewczenki, pyta:

- A kim on tam u was jest?

- No, poetą, bojownikiem o ideę narodową...

- Coś jak Żyrinowski?

- Nie, ten był cichy, spokojny. Pisał wiersze o kobietach... Takie, no, współczujące... ${ }^{25}$ (Kurkow 2008: 69).

Przywołanie w charakterze bojownika o ideę narodową skandalizującego rosyjskiego polityka zdecydowanie dewaluuje samo to pojęcie, czyni je komicznym, podobnie jak przypadkiem zasłyszane przez Nikołaja Sotnikowa na demonstracjach UNA-UNSO apele i hasła całkowicie zniechęcają go do polityki. Właśnie dlatego tak podobają mu się paradoksalne refleksje o patriotyzmie dysydenta Herszowicza, przenoszące to pojęcie ze sfery publicznej do sfery prywatnej:

Patriota absolutny nie uznaje ani większości, ani mniejszości narodowej. Jego miłość do kobiety jest silniejsza od miłości do ojczyzny, ponieważ kobieta, okazując wzajemność, staje się symbolem ojczyzny, ideałem patrioty absolutnego. Obrona kobiety, odwzajemniającej miłość, stanowi najwyższy przejaw patriotyzmu ${ }^{26}$ (Kurkow 2008: 6).

24 „- Во времена! - вздохнула она. - Раньше то по ленинским местам, то по Брежневским, а теперь у каждой республики свой идол".

25, „-А он у вас что?

- Да так, поэт, борец за национальную идею...

- Вроде Жириновского?

- Нет, он был тихий, спокойный. Стихи писал про женщин... такие, с жалостью".

26 „Абсолютный патриот не признаёт ни национального большинства, ни национального меньшинства. Его любовь к женщине сильнее любви к родине, потому что женщина, отвечающая взаимностью, и есть символ родины, идеал абсолютного патриота. Защита женщины, отвечающей взаимностью на любовь, и есть высшее проявление патриотизма". 
Bohater powieści Kurkowa wyrusza na piaszczysty półwysep Mangystau po rękopis Szewczenki i odnajduje swoją miłość w osobie Kazaszki Guli, podobnie jak bohater powieści Rakitinej odnalazł swoją miłość w osobie Seweryny-Haili, wypełniając misję wagi państwowej w okupowanej przez jego rodaków dalekiej Leitavie.

Co ciekawe, mimo obecności wyraźnego komponentu narodowego $\mathrm{w}$ analizowanych utworach Rakitinej i Kurkowa, powieści te zostały bardzo różnie w swoich krajach.

Białoruscy literaturoznawcy zareagowali na Gonitwę niezwykle życzliwie i od razu włączyli rosyjskojęzyczne dzieło do kontekstu literatury białoruskiej (Biazlepkina 193; Zaprudski 199-200; Ammon 19). Aksana Biazlepkina wymienia Gonitwe wśród sześciu najważniejszych utworów rosyjskojęzycznych w literaturze na Białorusi i wśród siedmiu najbardziej udanych utworów gatunku fantasy (Biazlepkina 156, 193). Badaczka fantastyki białoruskiej Maryna Ammon wyróżnia powieść Rakitiny spośród innych utworów należących do gatunku fantasy:

Główną przyczyną kryzysu gatunku w XXI wieku jest jego „pasożytnictwo" na gotowym zachodnioeuropejskim modelu folklorystyczno-mitologicznym, powielanym przez liczne teksty wzorcowe. Powrót gatunku fantasy do swoich korzeni jest możliwy o tyle, o ile autorzy sięgną do unikatowych kodów kulturowych swojego narodu, co jest szczególnie aktualne w kontekście rozwoju słowiańskiego fantasy (powieść Niki Rakitiny "Gonitwa") ${ }^{27}$ (Ammon 19).

Natomiast ukraińscy krytycy i literaturoznawcy praktycznie zignorowali Dobrego anioła śmierci. Autor z żalem zauważył, że powieść nie przyciągnęła uwagi pomimo ciężaru gatunkowego poruszonych w niej kwestii (Kurkow 2009). Być może zaważył tu wizerunek Kurkowa postrzeganego jako beletrysta, który wprawdzie odniósł sukces finansowy, daleko mu jednak do poziomu poważnej literatury.

Ale właś nie to, że wszystkie te kwestie, wyraziste etnoobrazy i stereotypy narodowe znalazły się nie $\mathrm{w}$ przełomowych dziełach znanych pisarzy białoruskich i ukraińskich, reprezentujących współczesny kanon literatury narodowej w swoich krajach i poza granicami, ale w utworach popularnych, adresowanych do masowego, rosyjskojęzycznego czytelnika, świadczy o aktualności problematyki narodowej i o wadze kategorii patriotyzmu dla postradzieckiej przestrzeni kulturalnej Europy Wschodniej.

Krótka analiza funkcjonowania etnoobrazó w i stereotypów narodowych w rosyjskojęzycznej literaturze Białorusi i Ukrainy na przykładzie debiutanckiej powieści

27 „Галоуунай прычынай крызісу жанру у̀ XXI ст. выступае яго „паразітаванне” на уужо гатовай заходнееу̃рапейскай фальклорна-міфалагічнай мадэлі, трансляванай праз шматлікія тэксты-каноны. Вяртанне фэнтэзі да першапачатковага інтэлектуальна-філасофскага падмурку магчымае пры звароце пісьменнікау да у̀нікальных культурных кодау̃ свайго народа, што асабліва актуальна у кантэксце развіцця славянскага фэнтэзі (раман Нікі Ракіцінай „Ганітва”)”. 
fantasy białoruskiej pisarki Rakitinej Gonitwa i powieści sensacyjnej znanego ukraińskiego beletrysty Kurkowa Dobry anioł śmierci prowadzi do następującego wniosku: odnosząc się do różnych literatur i różnych gatunków, ich dzieła przekonująco świadczą o efektywności i dobrych perspektywach odwoływania się współczesnych pisarzy do tradycji narodowej i twórczej gry z narodowymi kodami i obrazami.

\section{BIBLIOGRAFIA}

Ammon, Maryna. Sučasnaia belaruskaia litaraturnaia fantastyka: paetyka, typalogiia, kantekst. Minsk: Aŭtareferat, 2013.

Biazlepkina, Aksana. 100 sloŭ pra sučasnuiu belaruskuiu litaraturu. Minsk: Limaryus, 2012.

Kavalou, Siargey. „Rosyjskojęzyczna literatura wobec Białorusi: ekspansja czy tradycja wielokulturowości?". Porównania 15 (2014). S. 257-266.

Klinau, Artur. Shklatara. Minsk: Logwinaŭ, 2013.

Kowalow, Siergiej. „Pololingwizm kak osobiennost „malykh” literatur (na primierie razwitiia belorusskoi literatury v XVI veke)". Beloruskaia literatura kak model razvitiia "malyh" (slavianskih) literatur. Red. G.-B. Koler, P. Naumenko. Minsk: Biznesofset, 2013. S. 91-114.

Kurkow, Andrei. Dobryi Angel smierti. Kharkov: Folio, 2008.

Kurkow, Andrei. Ia napisal svoiu versiiu Evangelia. 2009. Web. 8.09.2016. <http://www.segodnya.ua/ life/interview/andrej-kurkov-ja-napical-cvoju-verciju-evanhelija.html>

Kurkow, Andrij. „Ukraińska kultura może odnosić sukcesy”. Raport o stanie kultury i NGO w Ukrainie. Red. P. Laufer. Lublin: Fundacja Kultura Enter, 2012. S. 149-158.

Lewis, Clive Staples. Opowieści z Narni. Przeł. Andrzej Polkowski. T. 1. Warszawa: Instytut Wydawniczy PAX, 1991.

Rakitina, Nika. Gonitwa. Minsk: Bukmaster, 2011.

Rasinski, Andrej. „Świt na kolonialnych ruinach”. Raport o stanie kultury niezależnej i NGO w Białorusi. Red. P. Laufer. Lublin: Fundacja Kultura Enter, 2011. S. 94-103.

Zaprudski, Igar. Metafizika belaruskai litaraturnai krytyki: artykuly, natatki, recenzii, vodguki. Minsk: BDU, 2013. 
